\title{
Chemical composition of corals in Saudi Red Sea Coast
}

\author{
Sultan S. AL-LIHAIBI ${ }^{\text {a*}, ~ A b d u l m o h s i n ~ A . ~ A L-S O F Y A N I ~}{ }^{\mathrm{b}}$, G. R. NIAZ ${ }^{\mathrm{a}}$ \\ ${ }^{a}$ Marine Chemistry Department, Faculty of Marine Science, King Abdulaziz University, PO Box 1540, Jeddah 21441, \\ Saudi Arabia \\ ${ }^{\mathrm{b}}$ Marine Biology Department, Faculty of Marine Science, King Abdulaziz University, PO Box 1540, Jeddah 21441, Saudi \\ Arabia
}

(Received 16/04/97, revised 27/05/98, accepted 29/05/98)

\begin{abstract}
Three species of corals Stylophora pistillata, Lobophyllia corymbosa and Echinopora gemmacea were collected from Sharm Obhur to study their chemical composition. This information was important in the investigation of their metabolic pathways and their mode of feeding. The concentrations of amino acids in these species were 9.37, 21.35 and $3.09 \mathrm{mg} \cdot \mathrm{g}^{-1}$ dry weight of coral respectively. Plant pigments were highest in E. gemmacea followed by S. pistillata and then by $L$. corymbosa. Lipid concentrations in S. pistillata, $L$. corymbosa and $E$. gemmacea were $1.90,8.58$ and 1.32 $\mathrm{mg} \cdot \mathrm{g}^{-1}$ of total coral respectively. The fatty acid methyl esters were analyzed in these species and the most abundant saturated acids were 16:0 and 18:0, while unsaturated acids included 16:1, 18:1 and 19:3. The carbohydrate concentrations were 559,425 and $859 \mu \mathrm{g} \cdot \mathrm{g}^{-1}$ of total coral dry weight. Residual matter was $42.5,32.8$ and 41.39 per cent by weight of total coral. These data suggest a greater reliance on autotrophic feeding in E. gemmacea and S. pistillata and mostly heterotrophic feeding in L. corymbosa. (C) Elsevier, Paris
\end{abstract}

\section{reef coral / chemical composition / nutrition}

Résumé - Composition chimique des coraux de la Côte de Mer Rouge en Arabie Saoudite. Trois espèces de coraux, Stylophora pistillata, Lobophyllia corymbosa et Echinopora gemmacea ont été prélevés à Sharm Obhur afin d'étudier leur composition chimique. Cette information est utile pour l'étude du métabolisme et du mode de nutrition des coraux. Les concentrations en acides aminés des trois espèces étaient respectivement de 9,37;21,35 et 3,09 $\mathrm{mg} \cdot \mathrm{g}^{-1}$. Les pigments végétaux sont plus importants chez E. gemmacea suivi par S. pistillata puis par L. corymbosa. Le contenu lipidique chez $S$. pistillata, L. corymbosa et $E$. gemmacea était respectivement de 1,$9 ; 8,58 \mathrm{et} 1,32 \mathrm{mg} \cdot \mathrm{g}^{-1} \mathrm{du}$ corail total. L'ester méthylique des acides gras a été analysé chez les trois espèces; les plus abondants parmi les acides saturés étaient le 16:0 et le 18:0, alors que les acides saturés comprenaient le 16:1, le 18:1 et le 19:3. Les contenus en hydrates de carbone des trois espèces étudiées étaient respectivement de 559,425 et $859 \mu \mathrm{g} \cdot \mathrm{g}{ }^{1}$; dans le même ordre la matière résiduelle représentait $42,5,32,8$ et $41,39 \%$ du poids total du corail. Ces données suggèrent une plus grande dépendance d'une nutrition autotrophe chez E. gemmacea el $S$. pistillata el une nutrition partiellement hélérotrophe chez L. corymbosa. (O Elsevier, Paris

\section{corail / composition chimique / nutrition}

\section{INTRODUCTION}

Corals have the ability to meet their nutritional needs from different sources [10]. Firstly they can biosynthe- size their own food directly by photosynthesis; secondly they can also consume zooplankton, phytoplankton, bacteria or tiny fish $[11,12,21]$. The nature of zooxanthellac also plays an important role in the growth of cor-

\footnotetext{
* Correspondence author
} 
als. It was stated by Porter [18] that corals possessing small polyps have a greater dependence upon autotrophic input than corals with large polyps which would be expected to have greater dependence upon heterotrophic plankton feeding. Fabricius et al. [4] have observed that the mode of feeding in the asymbiotic soft coral is herbivorous, while in the symbiotic stony coral the mode of feeding can be a combination of herbivorous and carnivorous.

The type of nutritional regime can also be studied by examining the chemical composition of the organism. Higher pigment and carbohydrate concentrations indicate a reliance on autotrophism, while higher protein and unsaturated lipid concentrations suggest that the organism relies at least in part un heterotrophism [13].

The Red Sea contains about 47 different genera of corals [2], estimated to include approximately 250 species. Most of these are stony corals, with a few soft corals. They have many different sizes of corallites and therefore exhibit different physiological adaptation to their marine environment. Echinopora gemmacea is an inactive coral which does not respond to changes in its environment and as such tentacles are withdrawn during the day. The corallites of this species are circular, averaging $5.6 \mathrm{~mm}$ in diameter and $8.8 \mathrm{~mm}$ in depth. Stylophora pistillata is a branching coral, commonly found in Sharm Obhur and is specially adapted to a wide range of light conditions. It has small corallites approximately $1.0 \mathrm{~mm}$ in diameter and $1.6 \mathrm{~mm}$ deep. Lobophyllia corymbosa has wide polyps and a considerable amount of mucus secretions as revealed by its high protein and lipid composition. It has large corallites $15 \mathrm{~mm}$ in diameter and $5-7 \mathrm{~cm}$ in length (single polyp, slipper coral; [20]).

The present study was designed to analyze the chemical composition and mode of energy acquisition in three coral species with vastly different polyp size from the Saudi Red Sea coast.

\section{MATERIALS AND METHODS}

The study area was selected within the Sharm Obhur, $35 \mathrm{~km}$ north of Jeddah. The Sharm runs in a SW-NE direction for about $9.3 \mathrm{~km}$ and has an average width of about $500 \mathrm{~m}$. An area of reef was chosen for the study on the northern side, just inside the entrance of Sharm (figure 1). The reef edge is in about $1 \mathrm{~m}$ of water and the reef front descends steeply to the sand at the base of the

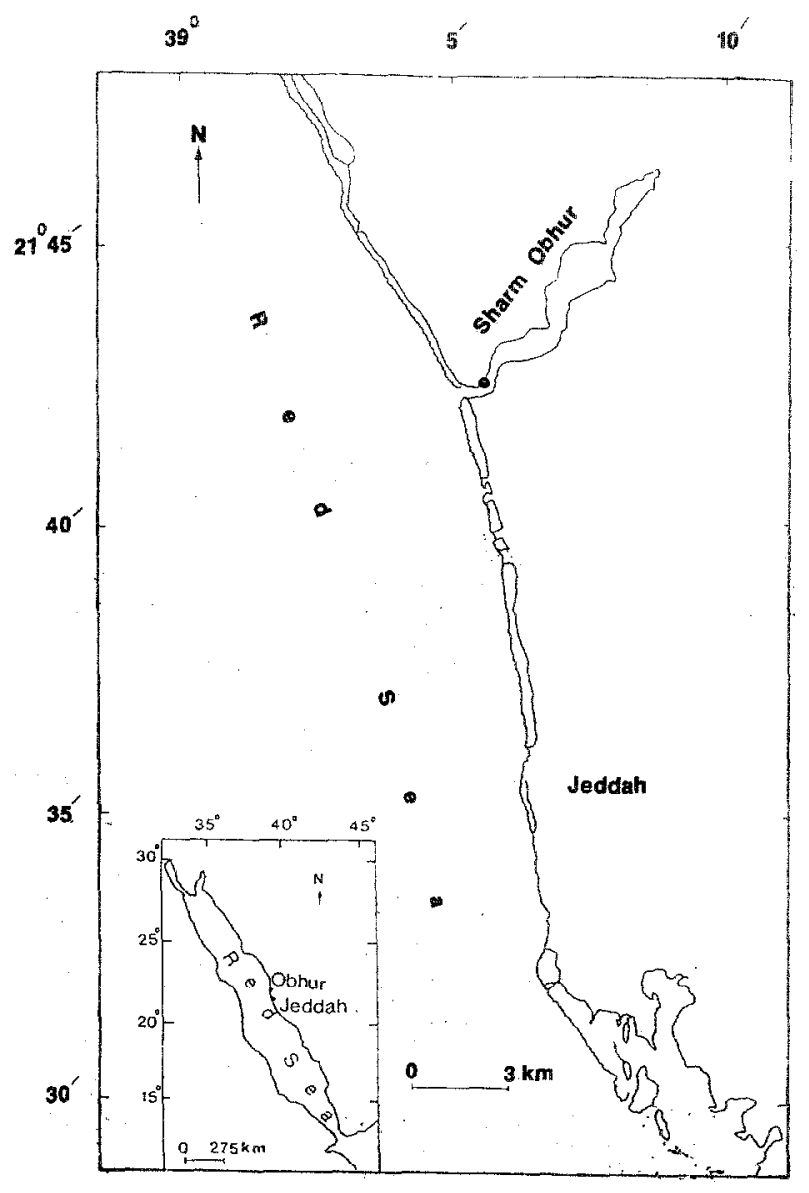

Figure 1. Location of coral samples from Sharm Obhur off Saudi Red Sea coast, $(\bullet$ ) sampling site.

channel. The inshore zone occupying the first $15 \mathrm{~m}$ from the shore line is characterized by bare rocks and dead coral fragments. Stylophora pistillata is dominant, with a percentage cover of approximately $35 \%$ at a depth of $2 \mathrm{~m}$. The colonies of this species were round with clustered thick branches. Echinopora gemmacea was found at a depth of 2-7.5 m accounting for about $5 \%$ of coral colonies. Lobophyllia corymbosa was found at a depth of $2 \mathrm{~m}$.

Corals were collected from the fringing reefs of Sharm Obhur, near Jeddah coast at a depth of $2 \mathrm{~m}$ during the months of November and December 1996. The average temperature of the sea was $29^{\circ} \mathrm{C}$, salinity 39.6 and $\mathrm{pH}$ 8.16. Fresh samples were used each time and the top $2 \mathrm{~cm}$ portion of the branch (nubbin) was involved in the analysis. The skeleton was examined under microscope 
(Leica, model-Wild M-3B; 120 times) and found clean and free of endolithic algae. The specimens (total coral) were washed with sea water and the skeletal density was determined by buoyant weighing in sea water and then in distilled water of known densities. Surface area was determined by weighing aluminum foil which had been cut and fitted to the coral surface. Water content was determined by drying the coral at $70^{\circ} \mathrm{C}$ for $72 \mathrm{~h}$ until a constant weight was reached. Residual matter was determined by heating in muffle furnace at $650^{\circ} \mathrm{C}$ for $24 \mathrm{~h}$ until a constant weight was reached.

The coral was ground to powder in a mortar. Carbohydrate and plant pigments were determined using UV visible spectrophotometer (Shimadzu, model 240A). Estimation of the carbohydrates using the anthrone method [8] was slightly modified, absorbance being recorded at $625 \mathrm{~nm}$. Standard solutions of glucose (Fluka, Co.) were treated similarly, and a calibration curve was drawn. $\Lambda$ known $40 \mu \mathrm{g} \cdot \mathrm{mL}^{-1}$ standard solution of glucose was mixed with a colony of Stylophora pistillata and it was observed that the recovery was $85 \%$. Chlorophyll was determined by treating an accurately weighed amount of coral powder with $90 \%$ acetone, occasionally shaking and then keeping it overnight in a refrigerator. One millilitre of supernatant was used to determine the amounts of chlorophyll a, b, c and phaeopigments spectrophotometrically at $480,630,645,665$ and $750 \mathrm{~nm}$ [19]. For amino acid analysis in coral proteins, dried coral powder was suspended in $6 \mathrm{M}$ hydrochloric acid in a sealed tube under nitrogen and hydrolyzed by heating at $10{ }^{\circ} \mathrm{C}$ for $24 \mathrm{~h}$. The hydrolysate was centrifuged for $15 \mathrm{~min}$ and supernatant liquid was freeze-dried to remove $\mathrm{HCl}$. These were reconstituted in a citrate buffer solution at $\mathrm{pH} 2.2$ and filtered through a $0.45 \mu \mathrm{m}$ filter. The solution was passed through a cation exchange resin column ( $15 \mathrm{~cm}$ long, $1 \mathrm{~cm}$ i.d.), to remove calcium (not detectable by atomic absorption). The residual material was applied to amino acid analyzer (Biotronik model LC-6001, resin type BTC-2710) and it was eluted with four different buffer solutions $A, B, C$ and $\mathrm{D}$ with a $\mathrm{pH}$ of $3.5,4.25,5.35$ and 10.2 respectively. Buffer flow rate was maintained at $20 \mathrm{~mL} \cdot \mathrm{h}^{-1}$. Initially all the known standard amino acids (Sigma, $20 \mathrm{nmol}$ ) were run and then the three coral sample solutions were applied to amino acid analyzer.

Lipids were extracted using the modified Folch method [5]; additional amounts of lipids were obtained by decalcifying the residual matter with $10 \%$ formic acid [6]. Lipids were separated by preparative layer chromatogra- phy on silica. Neutral lipids were isolated by developing the plate in hexane, ether and acetic acid (80:20:1). Phospholipids were isolated with chloroform, methanol, acetic acid and water $(65: 25: 4: 4, v / v)$. The spots were scraped, eluted with chloroform and filtered. After solvent evaporation, the lipid fractions were weighed to an accuracy of $0.1 \mathrm{mg}$. Methyl esters were prepared by hydrolysing the lipid with $1 \mathrm{M}$ ethanolic potassium hydroxide under reflux for one hour; it was extracted with ether and partitioned with water. The aqueous layer was neutralized with $5 \mathrm{M}$ hydrochloric acid and the free fatty acids were extracted with chloroform. The free fatty acids were dissolved in tetrahydrofuran containing $5 \%$ methanolic hydrogen chloride and the solution was refluxed for $2 \mathrm{~h}$. Water containing $5 \%$ sodium chloride was added, and the methyl esters were extracted with hexane. The hexane layer was washed with $2 \%$ potassium bicarbonate, dried over anhydrous sodium sulphate and the solvent evaporated in a stream of nitrogen. The fatty acid methyl esters were analyzed using gas chromatography (Shimadzu $17 \mathrm{~A})$ equipped with a fused silica capillary column $(30 \mathrm{~m}$ $\times 0.25 \mathrm{~mm}$ i.d.) coated with cross-linked SP-2310. The oven temperature was programmed from 150 to $250^{\circ} \mathrm{C}$ at $5^{\circ} \mathrm{C} \cdot \mathrm{min}^{-1}$, the final temperature was maintained for $5 \mathrm{~min}$. The samples were further analyzed using gas chro-

Table I. Skeletal density, tissue weight, chemical content, moisture and residual matter of three coral species off Saudi Red Sea coast. SD are given in brackets, $\mathrm{n}=\mathbf{3}$.

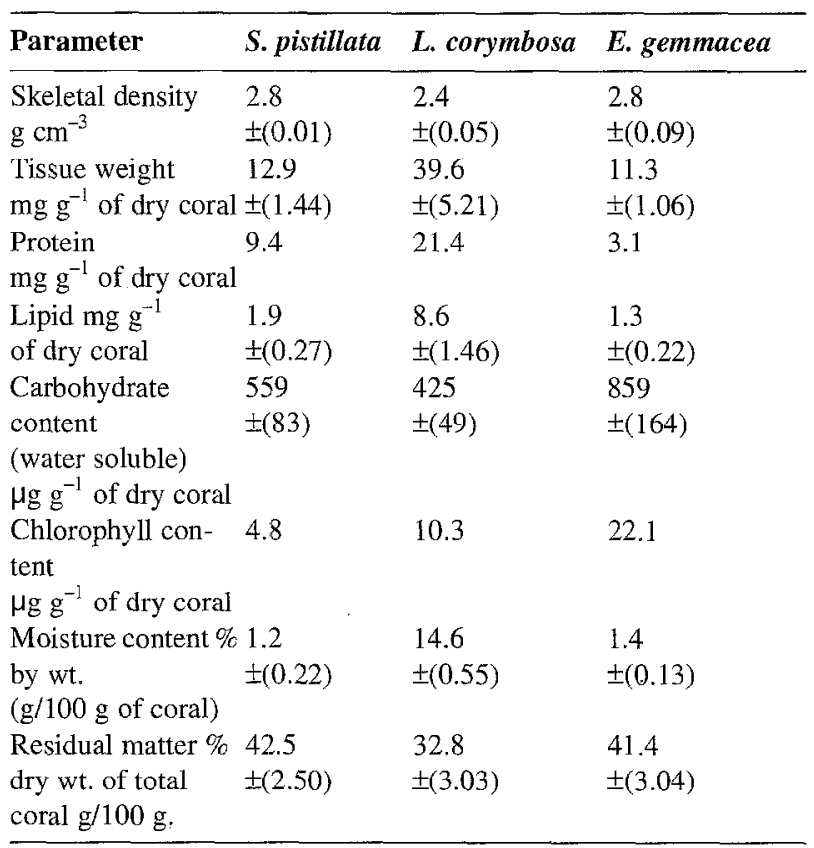


matography-mass spectrometry (GCMS) on Shimadzu QP-5000 quadrupole.

\section{RESULTS AND DISCUSSION}

The percentages of total amino acids derived from protein in Stylophora pistillata, Lobophyllia corymbosa and Echinopora gemmacea were $0.93,2.13$ and 0.30 (dry weight of total coral) respectively. Glutamic acid, aspartic acid, leucine, proline and glycine were the major amino acids (table $I$ ). The two acidic amino acids have also

Table II. Percentage of amino acids in three coral species from Sharm Obhur off Saudi Red Sea coast

\begin{tabular}{llll}
\hline Amino Acid & S. pistillata & L. corymbosa & E. gemmacea \\
\hline Aspartic Acid & 9.0 & 9.5 & 11.0 \\
Threonine & 3.8 & 5.8 & 4.2 \\
Serine & 4.3 & 6.1 & 4.9 \\
Glutamic Acid & 14.6 & 20.0 & 17.5 \\
Proline & 8.5 & 5.2 & 21.7 \\
Glycine & 8.1 & 14.9 & 9.7 \\
Alanine & 7.2 & 6.9 & 3.2 \\
Valine & 7.5 & 4.8 & 3.2 \\
Methionine & 2.8 & 1.7 & 0.3 \\
Isoleucine & 5.1 & 3.9 & 2.3 \\
Leucine & 10.7 & 8.3 & 7.1 \\
Tyrosine & - & - & 0.7 \\
Phenylalanine & 4.2 & 2.6 & 4.5 \\
Histidine & 7.8 & 5.3 & 6.2 \\
Lysine & 6.1 & 3.7 & 2.2 \\
Cystine & - & - & 0.7 \\
\hline
\end{tabular}

been reported to be the major constituents in marine algae [15] indicating the possibility that these were derived from the symbiotic algae in corals. The nature of the amino acids found in the corals are indicated in figure 2 . Neutral amino acids were most abundant and those containing sulphur were the least abundant. The following order of abundance was determined:

$$
\text { neutral }>\text { acidic }>\text { basic }>\text { aromatic }>\text { sulphur. }
$$

A comparative study of the amino acids according to their chemical type indicated glutamic acid was most abundant in Lobophyllia corymbosa. Among basic anino acids proline was unexpectedly high in Echinopora gemmacea $(21.7 \%)$, and low in Stylophora pistillata and Lobophyllia corymbosa. The neutral amino acids which formed the bulk of total amino acids indicated a high glycine content in Lobophyllia corymbosa (14.9\%) and comparatively low in the other two species. Both sulphur and the aromatic amino acids showed consistency, i.e. methionine was greater in all the three species than cystine. Similarly phenylalanine was greater in the three species than tyrosine. Tyrosine and cystine were below detection limits in Stylophora pistillata and Lobophyllia corymbosa. These same two amino acids were detectable in Echinopora gemmacea, but in very small amounts $(0.64$ and $0.65 \%$ respectively). Arginine was not detected and this may be due to the fact that it was probably masked by ammonia. In Stylophora pistillata, glutamic acid was found to be the most abundant followed by leucine and aspartic acid, these three making up $34.4 \%$ of total amino acids. In Lobophyllia corymbosa the most abundant amino acid was glutamic acid followed by glycine and aspartic acid, which accounted for about $50 \%$ of total amino acid present.

The total lipid content of Stylophora pistillata, Lobophyllia corymbosa and Echinopora gemmacea was found to be $14.8 \%, 21.5 \%$ and $11.8 \%$ (dry weight of coral tissue) respectively (table III). Wax esters (WE) and triglycerides (TG) were found to be the major components of the ester mixture. Collectively, these individual lipids were present to approximately the same extent in Stylophora pistillata as was reported by Harland et al. [7]. They reported a total of $17 \%$ of lipid (dry weight of coral tissue) while in this study the percentage was slightly lower $(14.8 \%)$. This may be due to seasonal variation [1, 17]. However, the pattern of distribution of individual lipids was similar. Harland et al. [7] reported the WE and TG to be 48.6 and $24.6 \%$ respectively, making a total of $73 \%$ of storage lipid (WE $+\mathrm{TG}$ ), while the present investigations indicate that the wax esters and triglycerides were $39.9 \%$ and $28 \%$ respectively, making a total of $68 \%$ for storage lipid. Phospholipids were low in Echinopora gemmacea and Stylophora pistillata (22\% and $14 \%$ of the total lipids, table $I I I)$, but considerably higher in Lobophyllia corymbosa ( $35 \%$ dry weight of total lipids). Although all three species were collected from the same location and had the same marine environment, there were marked differences in their biochemical composition. During the study of the methyl esters of fatty acids, it was observed that the even numbered fatty acids had the highest percentage composition, although fatty acids with odd carbon numbers were also represented in all three species. The most abundant fatty acids were palmitic acid 16:0 and stearic acid 18:0. Other 


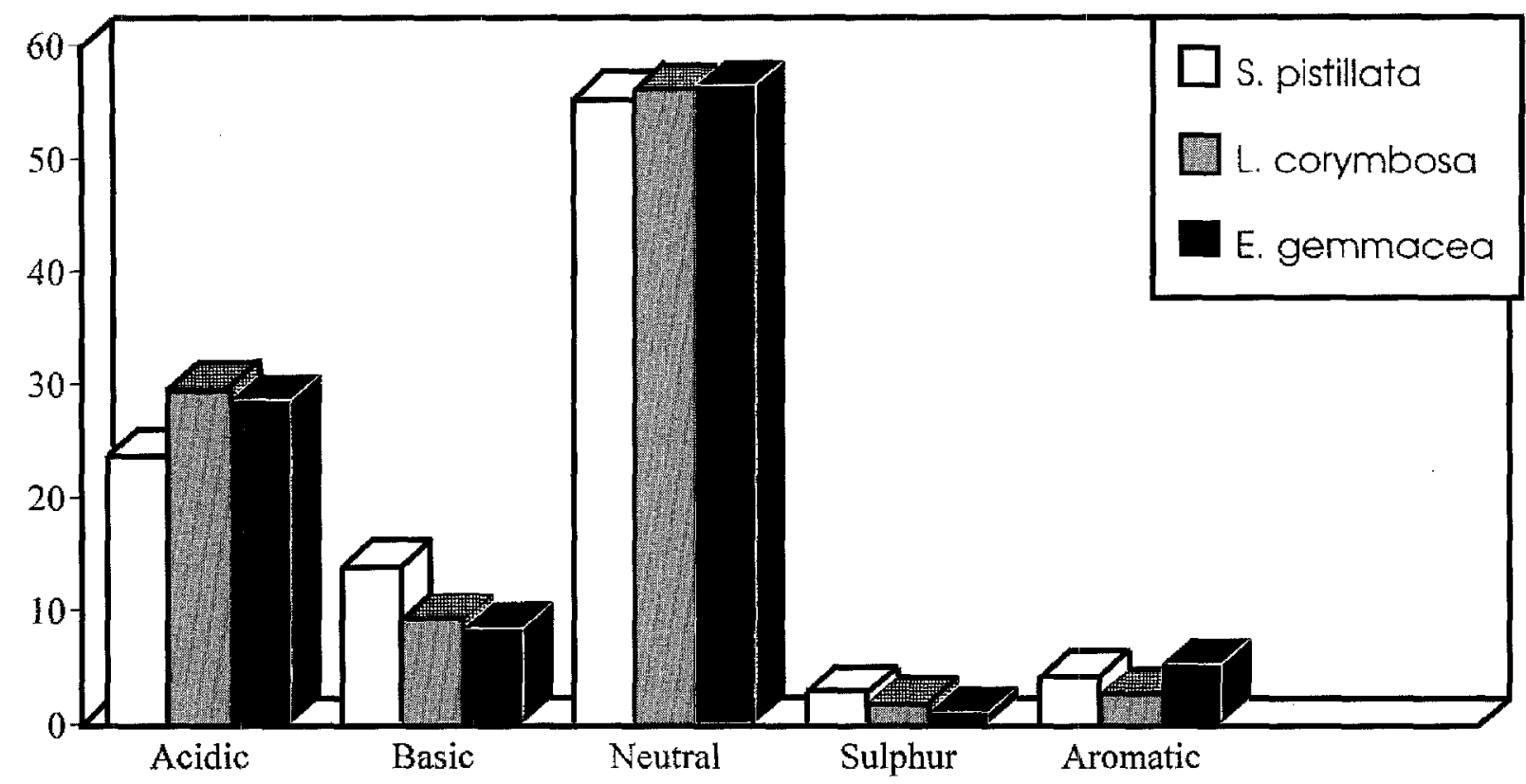

Figure 2. Profile of aminn acids (a) acidic, (b) basic, (c) nentral, (d) sulphur and (e) aromatic, in coral species from Sharm Obhur off Saudi Red Sea coast.

Table III. Percentage of total lipids and different classes of lipids in three specics of coral from Sharm Obhur. Standard deviations are given in parentheses, $n=3$. (\% of dry weight of coral tissue).

\begin{tabular}{llll}
\hline Class & S. pistillata & L. corymbosa & E. gemmacea \\
\hline Total lipid & 14.8 & 21.7 & 11.8 \\
& $(2.91)$ & $4.01)$ & $(2.01)$ \\
Wax ester & 5.9 & 8.4 & 5.9 \\
& $(1.14)$ & $(1.45)$ & $(0.60)$ \\
Triglycerides & 4.2 & 3.4 & 2.4 \\
& $(0.87)$ & $(1.43)$ & $(0.48)$ \\
Phospholipids & 3.3 & 7.8 & 1.6 \\
& $(0.84)$ & $(2.05)$ & $(0.36)$ \\
\hline
\end{tabular}

major fatty acids included 17:0, 18:1, 22:1 and 24:0 (table IV). Lobophyllia coryombosa differed significantly as it contained more unsaturated fatty acids, i.e. oleic acid (18:1) $13.1 \%$ and eicosatrienoic acid (19:3) $13.9 \%$, which were in comparatively lower quantities in the other two species. In summary, saturated fatty acids were more abundant in Stylophora pistillata and Echinopora gemmacea than unsaturated fatty acids, whereas in Lobophyllia corymbosa this picture was slightly different. Such variation in composition could be expected as it reflects the relative proportion of fatty acids from diet, algal pho-
Table IV. Percentage of fatty acid composition in the total lipids of three coral specics from Sharm Obhur off Saudi Red Sca coast. (trace $=0.05 \%$, nd $=$ not detectable $)$.

\begin{tabular}{llll}
\hline Fatty acids & S. pistillata & L. corymbosa & E. gemmacea \\
\hline $9: 1$ & 0.8 & nd & nd \\
$10: 1$ & tr & 0.8 & tr \\
$11: 1$ & 1.5 & tr & 1.3 \\
$11: 2$ & nd & 0.9 & nd \\
$12: 0$ & nd & 1.1 & 1.1 \\
$14: 0$ & 0.6 & 1.0 & 1.1 \\
$15: 0$ & nd & 0.6 & 1.3 \\
$16: 0$ & 21.8 & 12.9 & 30.7 \\
$16: 1$ & 2.3 & 1.4 & 2.0 \\
$16: 2$ & nd & nd & 8.7 \\
$17: 0$ & 9.6 & 2.6 & 1.5 \\
$17: 1$ & 3.2 & 1.6 & tr \\
$18: 0$ & 9.8 & 14.9 & 8.0 \\
$18: 1$ & 8.8 & 13.1 & 4.8 \\
$19: 0$ & tr & 3.1 & 6.8 \\
$19: 3$ & 0.9 & 13.9 & 5.2 \\
$20: 0$ & 4.3 & tr & tr \\
$20: 1$ & 5.2 & 2.4 & 3.9 \\
$20: 4$ & nd & 8.0 & nd \\
$21: 0$ & 6.5 & 1.0 & tr \\
$21: 1$ & nd & 2.4 & 5.5 \\
$22: 0$ & 4.8 & 0.8 & 7.2 \\
$22: 1$ & 3.2 & 2.3 & 5.7 \\
$23: 0$ & 5.5 & 2.2 & 1.4 \\
\hline & & &
\end{tabular}


Table V. Pigments in the three species of coral $\left(\mu \mathrm{gg} \mathrm{g}^{2}\right.$ of dry weight coral). Standard deviation is given in parentheses, $\mathrm{n}=3$.

\begin{tabular}{llll}
\hline & S. pistillata & L. corymbosa & E. gemmacea \\
\hline Chlorophyll 'a' & 0.9 & 2.6 & 5.0 \\
& $(0.44)$ & $(1.36)$ & $(2.51)$ \\
Chlorophyll 'b' & 0.4 & 1.0 & 3.1 \\
& $(0.15)$ & $(0.71)$ & $(0.77)$ \\
Chlorophyll 'c' & 2.9 & 4.9 & 11.5 \\
& $(1.1)$ & $(3.73)$ & $(4.86)$ \\
Carotenoids & 0.3 & 1.4 & 1.5 \\
& $(0.04)$ & $(0.39)$ & $(0.86)$ \\
Phaeopigments & 0.3 & 0.4 & 0.9 \\
& $(0.04)$ & $(0.04)$ & $(0.43)$ \\
\hline
\end{tabular}

tosynthesis and synthesis by animal tissue. It has been postulated that unsaturated lipids may be derived from the diet and saturated lipids from zooxanthellae $[14,16]$. An extensive study of the lipid composition of 45 samples of different coral species was carried out by Meyers [13]. He observed that most of the species had a low proportion of polyunsaturated fatty acids with dominance of palmitic acid (16:0) and stearic acid (18:0). It was concluded that those corals which depend heavily upon their symbiotic algae for lipogenesis will contain predominantly plant-like fatty acids, i.e. saturated fatty acids. Dubinsky et al. [3] found that the external environmental factors also influence the growth and composition of the corals. For example, it was observed that when Stylophora pistillata was exposed to external nutrient resources and feeding on Artemia; it led to an increase in the aerial pigmentation in comparison with control colonies [3].

Chlorophyll $a, b, c$, carotenoids and phaeopigments and carbohydrates were highest in Echinopora germmacea (table V), indicating great dependence on the primary products of photosynthesis. On the other hand, Lobophyllia corymbosa had lower carbohydrate content and a smaller quantity of plant pigments. The residual matter which is mostly calcareous in nature was found to be lower in Lobophyllia coryombosa (32.8\%) while it was high and almost in equal quantity in Stylophora pistillata $(42.5 \%)$ and Echinopora gemmacea $(41.4 \%)$. The presence of zooxanthellae affects the calcification rate in hermatypic corals [9].

\section{CONCLUSIONS}

Corals procure their food from symbiotic, photosynthetically active zooxanthellae. These hermatypic corals can also be partly microcarnivorous feeding on planktons. Thus corals maintain a balance between autotrophy and heterotrophy. Three coral species from a common location were examined for their biochemical composition. It was observed that saturated fatty acids were more abundant in Stylophora pistillata and Echinopora gemmacea indicating a greater reliance on symbiotic zooxanthellae. Unsaturated fatty acids were more abundant in Lobophyllia coryombosa indicating a higher level of feeding on zooplankton, as these unsaturated fatty acids are normally less common in zooxanthellae. The amino acid content of proteins was highest in Lobophyllia coryombosa; it was seven times higher than Echinopora gemmaceae, and more than twice that in Stylophora pistillata. $\Lambda$ possible explanation is that the feeding tentacles surrounding the mouth are capable of entrapping prey. Greater reliance on photosynthesis would be reflected in higher carbohydrate content as the primary product of photosynthesis. This has been found to be highest in Echinopora gemmacea and then in Stylophora pistillata and lowest in Lobophyllia coryombosa. One can speculate that Lobophyllia coryombosa, with its wider polyp, low saturated fatty acid and high protein levels probably procures its nutritional inputs not only through symbiotic algae but also from sources like zooplankton, small fish or fish faeces, while in Echinopora gemmaceae and Stylophora pistillata with its plant-like saturated fatty acids, comparatively low protein content and greater residual or calcareous material indicates its reliance on the primary products of photosynthesis.

\section{Acknowledgments}

The authors are grateful to Pr. Zafar Zaidi, H. E.J. Institute of Chemistry, University of Karachi for providing necessary facilities for amino acid analysis. The research described in this article has been funded partly by COMSTECH organization.

\section{REFERENCES}

[1] Davies P.S., Effect of daylight variations on the energy budget of shallow water corals, Mar. Biol. 108 (1991) 137-144.
[2] Ditlev H., Reef building corals of Indo-Pacific, W. Backhys Publishers, Rotherdam (1980) p. 1. 
[3] Dubinsky Z., Stamber N., Ben-Zion M., McCloskey L.R., Muscatine L., Falkowski P.G., The effect of external nutrient resources on the optical properties and photosynthetic efficiency of Stylophora pistillata, Proc. R. Soc. B. Biol. Sci. 239, 1295 (1990) 231-246.

[4] Fabricius K.E., Benayahu Y., Genin A., Herbivoiry in asymbiotic soft corals, Science 268 (1995) 90-92.

[5] Folch J., Lees M., Sloan-Stanely G.H., A simple method for the isolation and purification of total lipids from animal tissues, J. Biol. Chem. 226 (1957) 497-509.

[6] Harland A.D., Davies P.S., Fixture L.M., Lipid content of some Caribbean corals in relation to depth and light, Mar. Biol. 113 (1992) 357-361.

[7] Harland A.D., Navarro J.C., Davies P.S., Fixture L.M., Lipids of some Caribbean and Red Sea corals, total lipids, wax esters, triglycerides and fatty acids, Mar. Biol. 117 (1993) 113-117.

[8] Hewitt B.R., Spectroscopic determination of total carbohydrates, Nature 182 (1958) 246-247.

[9] Jacques T.G., Marshall N., Pilson M.E.Q., Experimental ecology of temperate scleratinian corals Astrangia danae, Mar. Biol. 76 (1983) 135-148.

[10] Johannes R.E., Cole S.E., Kuenzel N.T., The role of zooplankton in nutrition of some scleractinian corals, Limnol. Oceanogr. 15 (1970) 579-586.

[11] Lewis J.B., Process of organic production on coral reef, Biol. Review. 52 (1977) 305-347.

[12] Lewis J.B., Hetrotrophy in corals- Zooplanktopn predation by the hydrocoral Millepora complanata. Mar. Ecol. Prog. Ser. 90 (3) (1992) 251-256.
[13] Meyers P.A., Fatly acids and liydrocarbons of Caribbean corals, Proc. of 3rd Int. Coral Reef Symposim, Miami (1977) $529-536$.

[14] Meyers P.A., Polyunsaturated fatty acids in corals, indicators of nutritional sources, Mar. Biol. Lett. 1(2) (1979) 69-75.

[15] Munda J.M., Gubenesk F., The amino acid content of some benthic marine alyae from North Adriatic, Bol. Mar. 29 (1986) $367-372$.

[16] Patton J.S., Abraham S., Benson A.A., Lipogenesis in the intact coral Pocillopora capitata and its isolated zooxanthellae, Mar. Biol. 44 (1977) 235-247.

[17] Pollero R.J., Lipid and fatty acid characterization and metabolism in the sea anemone Phymactis clematis, Lipid 18 (1983) $12-17$.

[18] Porter J.W., Autotrophy, heterotrophy and resources partitioning in Caribbean reef building corals, Am. Nat. 110 (1976) $731-742$.

[19] Richards F.A., Creitz G.I., Estimation and characterization of plankton population by pigment analysis, J. Mar. Res. 14 (1955) 211-216.

[20] Sofyani A.A., Physiology and ecology of Stylophora pistillata and Echinopora gemmacea from the Red Sea. Ph.D. Thesis, Glasgow University, (1991) 164 p.

[21] Sorokin Y.I., On the feeding of some scleratinian corals with bacteria and dissolved organic matter, Limnul. Oceanogr. 18 (1973) 380-385. 